\title{
230Th DATING OF THE SPELEOTHEMS FROM THE "GROTTA DEL FIUME -GROTTA GRANDE DEL VENTO" KARST SYSTEM IN FRASASSI (Ancona, Italy) AND PALEOENVIRONMENTAL IMPLICATIONS
}

\author{
Adriano Taddeucci* ${ }^{*}$ Paola Tuccimei* and Mario Voltaggio**
}

\begin{abstract}
Chronological measurements have been-carried out on speleothems from the «Grotta del Fiume-Grotta Grande del Ventow karst system in Frasassi (Ancona, Italy) by means of the ${ }^{230} \mathrm{Th}$ radiometric method in order to date hypogean karst levels and related geological events. Higher levels were found to be older than the lower ones according to standstills and sinkings of the water table.

The dated speleothems from the first and second level formed less than 10,000 years ago; the minimum ages of the third and fifth levels, which are respectively 130,000 and 200,000 years old, were correlated to climatic events.

Dating different portions of a spelothem allows the measurements of the radial and vertical accretion rates and their variation over time. Such data together with the ${ }^{234} \mathrm{U} / 238 \mathrm{U}$ activity ratio and the uranium content of the speleothems have been correlated with the climatic variations connected to the glacial cycles. The same data have been used to fit a hydrogeological model.
\end{abstract}

\section{RIASSUNTO}

[Datazione col metodo del 230Th di concrezioni provenienti dal sistema carsico "Grotta del Fiume - Grotta Grande del Vento» presso Frasassi (Ancona) e correlazioni paleoambientali ]

La cronologia di alcune concrezioni provenienti dal sistema carsico «Grotta del FiumeGrotta Grande del Vento» è stata studiata datando col metodo del ${ }^{230} \mathrm{Th}$ i livelli carsici e gli eventi geologici ad essi correlati. I livelli superiori sono risultati più vecchi di quelli inferiori in accordo con $i$ progressivi approfondimenti della falda freatica.

Le concrezioni datate provenienti dal primo e secondo livello si sono formate 10.000 anni fa; le età minime del terzo e quinto livello, che sono, rispettivamente, 130.000 e 200.000 anni, sono state correlate con gli eventi climatici.

La datazione di diverse porzioni di una stessa concrezione permette la determinazione del rateo di accrescimento radiale e verticale e la sua variazione nel tempo. Tali risultati insieme al rapporto di attività ${ }^{234} \mathrm{U} / 238 \mathrm{U}$ a ed alla concentrazione dell'uranio nelle concrezioni stesse sono state correlate con le variazioni climatiche connesse con $i$ cicli glaciali. Gli stessi dati sono stati utilizzati per costruire un modello idrogeologico.

\section{INTRODUCTION}

Dating speleothems by ${ }^{230} \mathrm{Th}$ method (Gascoyne et al., 1978) is a powerful tool for Earth Sciences to improve the knowledge on subjects such

\footnotetext{
* Dip. Scienze della Terra, Univ. "La Sapienza", ROMA (Italy)

** Centro St. Quatern. Evol. Amb., c/o Dip. Scienze della Terra, Univ. "La Sapienza", ROMA (Italy)
} 


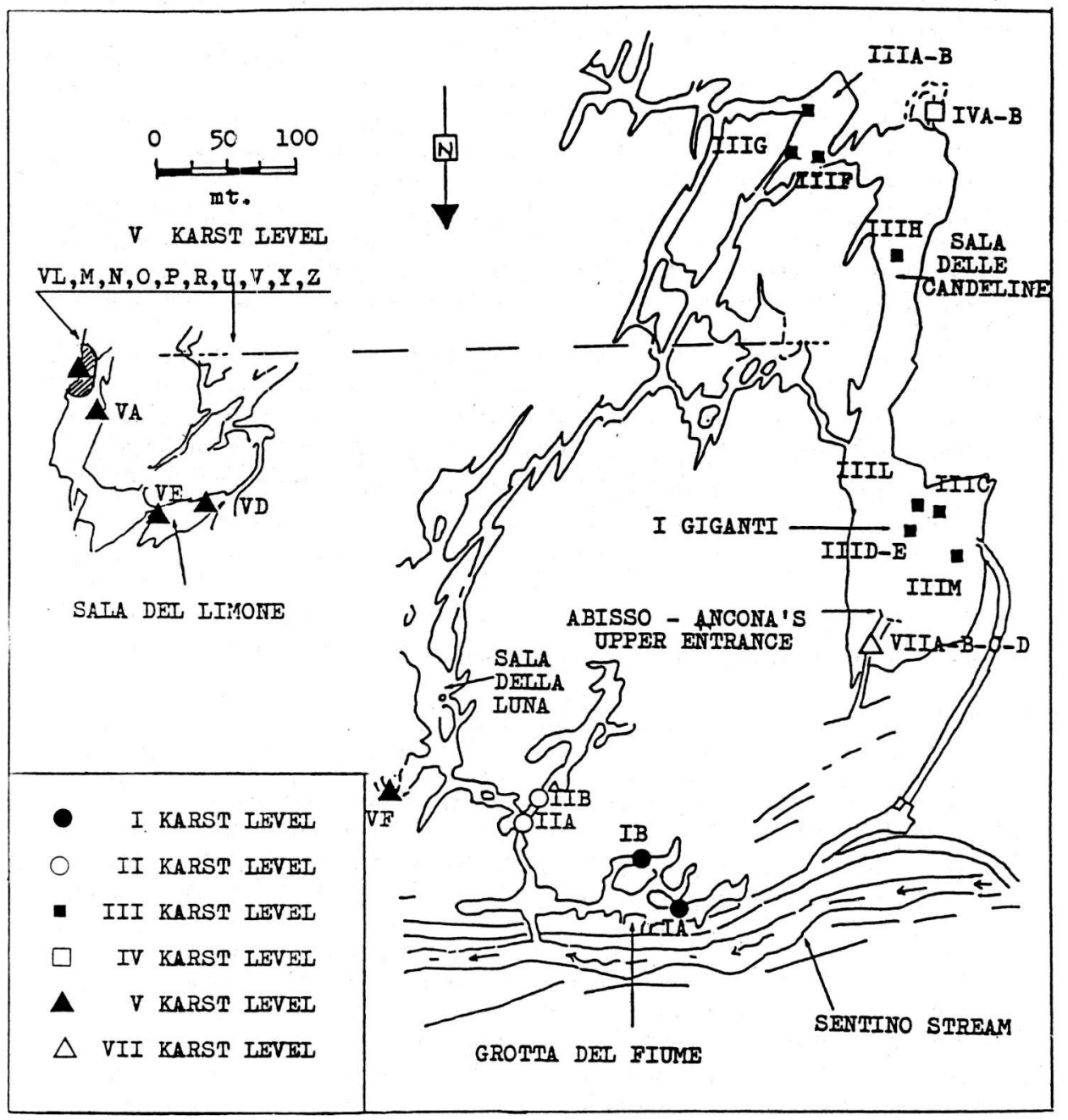

Fig. 1 - Locations of the speleothems sampled from the karst levels 
as karst evolution, neotectonics, palaeoclimatology. The «Grotta del FiumeGrotta Grande del Vento» karst system in Frasassi (Ancona, Italy) offers a unique situation: it covers a rather wide area (several square kilometers) well known from a geological point of view, interested by seven karst levels (Bocchini \& Coltorti, 1978a, b) over 210 meters of vertical spread; an efficient management allows a quite good preservation of the environment and offers facilities to the interested scientists.

On this basis we carried out a research in order to improve the knowledge of the karst evolution in terms of dates related to the concretionary stages. Moreover, the rate of accretion can be measured for the speleothems, giving indications on the palaeoclimate; finally, the data on $U$ content and its isotopic composition can be used for speculations on palaeohydrogeology. All analyses have been performed by means of alpha spectrometry.

\section{SAMPLING}

This research deals with more than 20 stalagmites (and a stalagmitic flowstone) from the 1st to the 5th karst level (Fig. 1).

The base and the top of some stalagmites have been dated; one has been sampled along its vertical axis by collecting 11 subsamples; others have been horizontally drilled to obtain a $2.5 \mathrm{~cm}$ diameter core reaching generally the nucleus of the stalagmite at its base; $10 \mathrm{~cm}$ long portions of such cores have been dated.

\section{ANALYTICAL DATA}

Elemental, isotopic (activity ratio) and age data are displayed in Tab. 1. It is very important to point out right now that the interpretation of the age data must be carried out only after a very careful evaluation of their validity. In fact, at least two kind of situations can occur to unvalidate the measured ages.

The first one depends on the sampling direction related to the conditions of accretion. Two examples are shown in Fig. 2. If the speleothem accreted as a sequence of vertical (Fig. 2a) or horizontal (Fig. 2b) concretionary sheets, it is quite evident that a set of subsamples along an horizontal core can give the same age, or that an inner subsample can appear to be younger than the outer ones. This can be the case of sample FRS $3 \mathrm{H}$ and FRS $3 E$ respectively.

The second situation probably occured during the accretion of sample FRS III $\mathrm{B}$; in this case, it is very probably correct to assume a uranium mobilization responsible for the modification of the ${ }^{230} \mathrm{Th} /{ }^{234} \mathrm{U}$ activity ratio. Consequently, the basic assumption of the method which requires a chemically and isotopically closed system since the deposition of the speleothem, could not be fulfilled.

Anyway, it must be emphasized that if a cluster of subsamples, large 

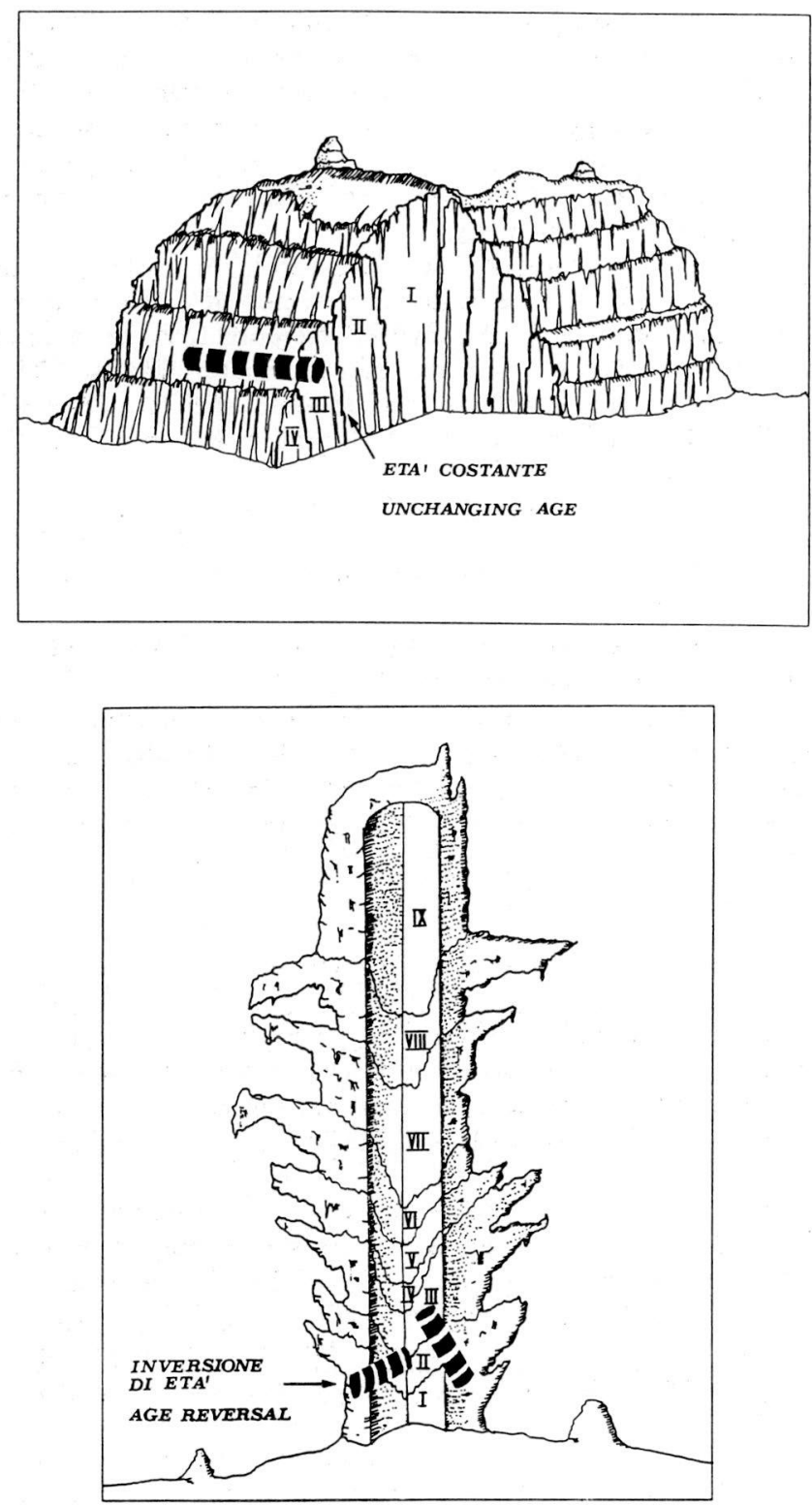

Fig. 2a and 2b - Relationships among sampig directions, accretion conditions and ages of speleothems (see text) 
enough to be considered as a closed system, is defined, the average age of the whole cluster is stratigraphically consistent. Obviously, the values related to these stalagmites have never been used for the following discussions.

\section{THE CHRONOLOGY OF THE KARST EVOLUTION}

In Tab. 2 the ages of speleothems are related to the evolution of the karst process, by taking into account only the oldest measured age for each level, with the assumption that the beginning of the concretionary phase took place just after the end of the formation of the same karst level. The probability that the measured age approaches the oldest one depends on the number of the dated samples; for this reason we can assume, as reasonably reliable, only the age of 130,000 years (Riss-Würm) for the 3rd level and that of 200,000 years for the 5th level (Mindel-Riss). Because of the few dated samples, an age of less than 10,000 years can be considered reasonable for the $1 \mathrm{st}$ and the 2nd karst levels, according to their poor concretioning.

Sampling will be extended in the future in order to give a better reliability to the dates and to obtain ages for the other karst levels also.

The variations of vertical and radial accretion rates are shown in Fig. 3. A sharp increase between 130,000 and 70,000 years could be related to the Riss-Würm interglacial climate that, according to Bortolami et al. (1977), was warm and wet in our region. A second increase which ranges from 30,000 years to present, is related to the post-Würm interglacial. The direct correlation of the concretioning to the precipitation has been also stated by Hennig et al. . (1983) and Gascoyne and Schwarcz (1982).

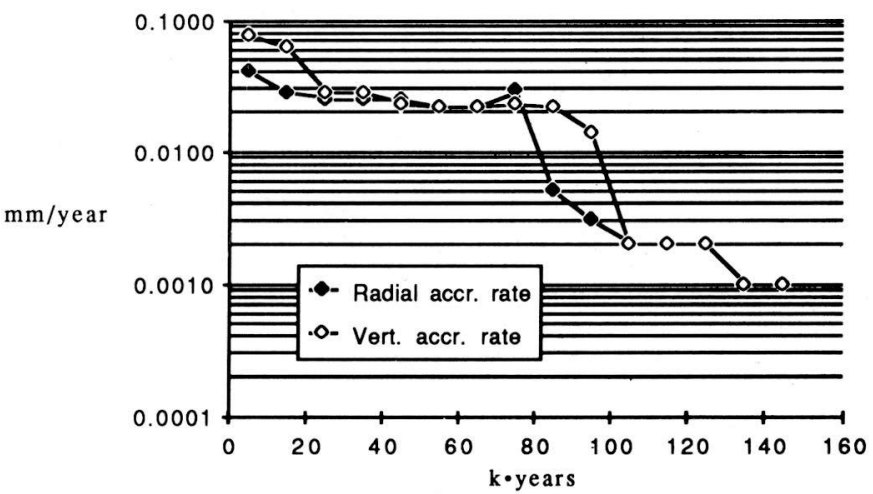

Fig. 3 - Variations of the vertical and radial accretion rates of the speleothems in the last 130,000 years.

During the Würm glacial period the accretion rates remained stationary, whereas their decrease could be expected. We believe that the lower amount 
of circulating water and the consequent lower amount of dissolved carbonate could have been compensated by the longest residence time of the seepage water in the wall-rock due to the deepening of the base level.

\section{PALEOHYDROGEOLOGY}

The climatic factors as temperature and precipitation, together with the pedology and the lithology of the region interested by the percolation water affect the dissolved uranium concentration and its isotopic composition. In fact, the interaction of carbon dioxide-rich waters with the carbonate wall rocks will result in their dissolution with the enrichment of the water in uranium with a ${ }^{234} \mathrm{U} / 238 \mathrm{U}$ activity ratio close to the unity. On the other side, during the interaction of less acid water with the carbonate wall-rocks, the leaching will prevail over the dissolution: the water will contain a smaller amount of uranium characterized by higher ${ }^{234} \mathrm{U} / 238 \mathrm{U}$ activity ratio, due to the easier leacheability of ${ }^{234} \mathrm{U}$ lying in "hot» sites (Fleischer, 1980). The leaching of non-carbonate rocks will result in waters richer in uranium, with a higher isotopic ratio (Taddeucci et al. 1987).

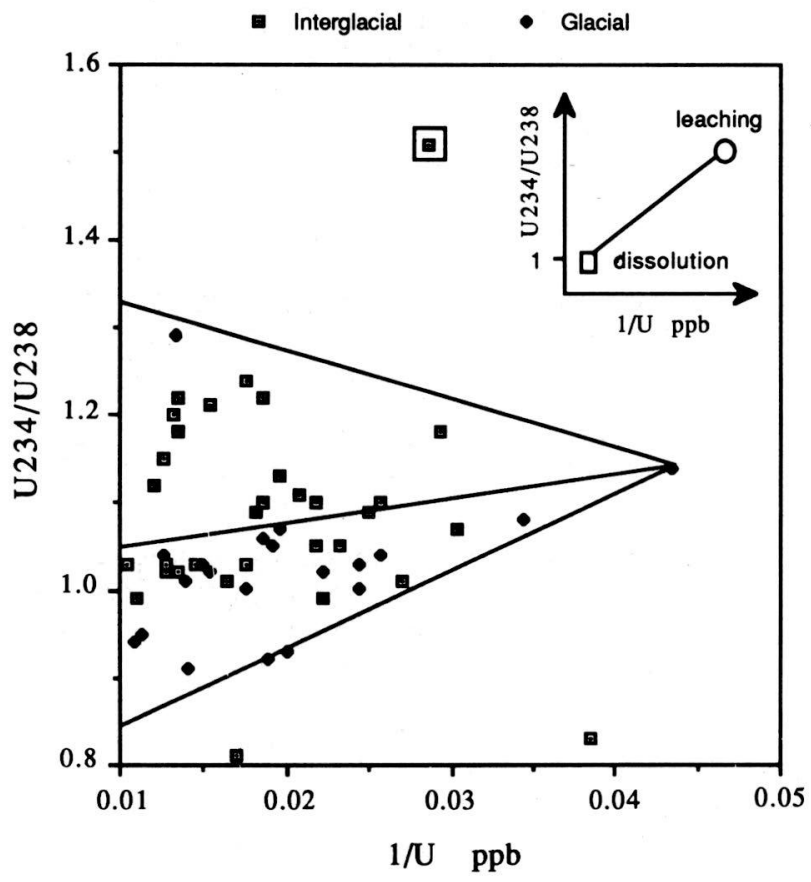

Fig. 4 - Initial uranium isotopic composition of the speleothems versus the reciprocal value of their uranium content. 
In Fig. 4, the initial uranium isotopic composition of the speleothems, corresponding to that of the deposition water, is plotted versus the reciprocal value of their uranium elemental content (black circles refer to material deposited during glacial periods, and open squares to the interglacials). "Cold» samples seem to lye on an array that can be explained in terms of mixing between two end members; the first one (square in the insert) refers to «dissolved uranium» water and the second one (circle in the insert) refers to «leached uranium» water interacting in a lithologically homogeneous reservoir; the low uranium content of the «leached» end member (extreme right valve in the figure) agrees with the existence of a carbonate reservoir.

By taking into account the "warm" samples, a third end member must be considered, represented by waters leaching (more than dissolving) uranium-rich rocks, different from carbonates (marls and clayey marls). This is compatible with an interglacial warm-wet climate, when the abundant rainfall was responsible for a better hydrologic connection among lithologically different reservoirs.

Double square in Fig. 4 represents a very interesting case dealing with a small stalagmite from the 5 th karst level (FRS VF) only 5 centimeters high, overlying a cherty archaeological artefact and connected to a palaeolithic fireplace with bones. The ${ }^{230} \mathrm{Th}$ age integrated over the whole stalagmite (due to its small size) turned out to be 1,500 \pm 400 years; the same speleothem has been dated by means of ${ }^{14} \mathrm{C}$ method by Prof. G. Calderoni (Earth Science Department, University of Rome «La Sapienza») and gave the age of 1 , $700 \pm 100$ years. The ${ }^{14} \mathrm{C}$ age of fire carbons and bones is $13,000 \pm 100$ years, that can therefore be assumed as the age of the artefact.

It is worthwhile to note that the ${ }^{230} \mathrm{Th}$ and the ${ }^{14} \mathrm{C}$ ages agree within the limit of the errors; that means that no carbon exchange occurred between the seepage water and the «infinite age ${ }^{14} \mathrm{C}$ » carbonate wall-rock. This conclusion is in agreement with the low uranium content and the very high isotopic ratio shown by the depositing water that had to be a typical «leaching» one.

\section{CONCLUSIONS}

The work that has been carried out identifies at least two dates within the whole evolution of the karst system: 130,000 and 200,000 years respectively for the end of the formation of the 3rd and 5th karst levels. Also the variations over time of the speleothems accretion rate agree with the palaeoclimatic conditions. The uranium content and its isotopic composition calculated for the carbonate-depositing waters have been used to figure out a hydrogeologic model involving a mixing among three end-members:

i) «dissolving» waters in a carbonate reservoir

ii) «U-leaching» waters in the same carbonatic reservoir

iii) «U-leaching» waters in a non-carbonate reservoir.

The first and second end-members prevail during the glacial period 
while the third one prevails during the interglacial period.

The high accretion rate of the speleothems occurring over the last thousands of years can be regarded as an index of the good "state of health" of the cave, at least from the tourist point of view. Because of the intense anthropization now occurring, we think that it should be easy and quite inexpensive to survey the accretion rate of carbonate concretions simply by periodically weighting some standard concretioning objects, appropriately located within the cave.

\section{ACKNOWLEDGEMENTS}

This research was carried on thanks to the generous contribution of the "Consorzio Frasassi» by an appropriate grant and a post-graduate fellowship, in the frame of a research contract stipulated with the Earth Science Department, University of Rome «La Sapienza».

We like to thank Mr. Giancarlo Marinelli and Mr. Terzo Marinelli together with all the personnel working for the Consorzio, since their friendly help is making possible our work in the cave.

Dr. Mauro Coltorti and Mr. Andrea Bocchini gave us a precious help for sampling the speleothems out of the touristic trail. The Scientific Committee of the Consorzio encouraged this work and gave us the most precious advises.

\section{REFERENCES}

Bocchini A. \& Coltorti M.,1978a - Rilievo topografico e geomorfologico del complesso carsico Grotta del Fiume (8 MA - AN) Grotta Grande del Vento (307 MA - AN). Atti XIII Cong. Naz. Speleol., Perugia 30 sett. - 4 ott. 1978. Preprints, Gruppo Spel. CAI Perugia.

Bocchini A. and Coltorti M., 1978b - Considerazioni sulla speleogenesi della zona carsica di Frasassi (AN) in relazione all'evoluzi one geomorfologica esterna. Atti XIII Cong. Naz. Speleol., Perugia 30 sett. - 4 ott. 1978. Preprints, Gruppo Spel. CAI Perugia.

Bortolami G.C., Fontes J.F., Markgraf V.,Saliege J.F., 1977 - Land, see and climate in the northern adriatic region during late pleistocene and holocene. Palaeogeography, Palaeoclimatology, Palaeoecology, 21: 139156.

Fleisher R.L., 1980 - Isotopic disequilibrium of uranium: alpha-recoil damage and preferential solution effects. Science, 207: 979- 981.

Gascoyne M. \& Schwarcz H.P., 1982 - Carbonate and sulphate precipitates. in: Ivanovich H. \& Harmon R.S. (Eds.) Uranium series disequilibrium Application to environmental problems. Oxford, Clarendon Press: 268300.

Hennig G.J., Grün R., Brunnacker K., 1983 - Speleothems, travertines and palaeoclimates. Quaternary Research, 20:1-29.

Taddeucci A., Voltaggio M., Conte A., 1987 - Datazione col 230Th di alcuni speleotemi del complesso carsico "Grotta del Fiume-Grotta Grande del Vento» a Frasassi (AN). Boll. Soc. Geol. It., 106: 807-812. 
Table 1 - Analytical data. Roman numerals refer to the karst level, letter to the speleothem and arabic numerals to its parts. All speleothems are stalagmites except FRS 4 which is a stalagmitic flowstone. For each sample in the first row are reported the values while in the second row are reported the errors.

\begin{tabular}{|c|c|c|c|c|c|c|c|c|}
\hline Sample & ubsample & $\begin{array}{l}\text { Period } \\
\text { (Glacial } \\
\text { or } \\
\text { Interglacial) }\end{array}$ & ppb & $\begin{array}{l}234 \mathrm{U} \\
238 \mathrm{U}\end{array}$ & $\begin{array}{c}234 \mathrm{U} \\
238 \mathrm{U}\end{array}$ & $\begin{array}{c}{ }^{230} \mathrm{Th} \\
-\mathrm{-T} \\
{ }^{232} \mathrm{Th} \\
\text { (initial) }\end{array}$ & $\begin{array}{r}230 \mathrm{Th} \\
234 \mathrm{U}\end{array}$ & $\begin{array}{c}\text { Age } \\
k \bullet \text { years }\end{array}$ \\
\hline FRS I A2 & top & I & $\begin{array}{r}96 \\
3\end{array}$ & $\begin{array}{l}0.99 \\
0.04\end{array}$ & $\begin{array}{l}1.03 \\
0.04\end{array}$ & $\begin{array}{r}1 \\
0.1\end{array}$ & $\begin{array}{l}0.05 \\
0.02\end{array}$ & 10 \\
\hline FRS II A1 & base & I & $\begin{array}{r}78 \\
3\end{array}$ & $\begin{array}{l}1.03 \\
0.03\end{array}$ & $\begin{array}{l}1.03 \\
0.03\end{array}$ & $\begin{array}{r}1 \\
0.1\end{array}$ & $\begin{array}{l}0.07 \\
0.02\end{array}$ & 10 \\
\hline FRS II A2 & top & I & $\begin{array}{r}33 \\
2\end{array}$ & $\begin{array}{l}1.06 \\
0.08\end{array}$ & $\begin{array}{l}1.07 \\
0.08\end{array}$ & $\begin{array}{r}3 \\
0.2\end{array}$ & $\begin{array}{l}0.08 \\
0.02\end{array}$ & 10 \\
\hline FRS II B1 & base & I & $\begin{array}{r}74 \\
4\end{array}$ & $\begin{array}{l}1.22 \\
0.06\end{array}$ & $\begin{array}{l}1.22 \\
0.06\end{array}$ & $\begin{array}{r}2 \\
0.1\end{array}$ & $\begin{array}{l}0.03 \\
0.01\end{array}$ & 10 \\
\hline FRS III A1 & base & I & $\begin{array}{r}79 \\
5\end{array}$ & $\begin{array}{l}1.11 \\
0.06\end{array}$ & $\begin{array}{l}1.15 \\
0.06\end{array}$ & $\begin{array}{r}24 \\
4\end{array}$ & $\begin{array}{l}0.60 \\
0.05\end{array}$ & $\begin{array}{r}93 \\
+13-11\end{array}$ \\
\hline FRS III A3 & top & G & $\begin{array}{r}50 \\
3\end{array}$ & $\begin{array}{l}0.94 \\
0.02\end{array}$ & $\begin{array}{l}0.93 \\
0.02\end{array}$ & in $\mathrm{f}$. & $\begin{array}{l}0.40 \\
0.03\end{array}$ & $\begin{array}{r}55 \\
5\end{array}$ \\
\hline FRS III B1 & base & I & $\begin{array}{r}55 \\
4\end{array}$ & $\begin{array}{l}1.06 \\
0.07\end{array}$ & $\begin{array}{l}1.09 \\
0.07\end{array}$ & $\begin{array}{r}32 \\
5\end{array}$ & $\begin{array}{l}0.70 \\
0.04\end{array}$ & $\begin{array}{r}130 \\
+15-14\end{array}$ \\
\hline FRS III B2 & $\begin{array}{l}4.5-9 \mathrm{~cm} \\
(\text { upwards) }\end{array}$ & G & $\begin{array}{r}65 \\
3\end{array}$ & $\begin{array}{l}1.01 \\
0.04\end{array}$ & $\begin{array}{l}1.02 \\
0.04\end{array}$ & $\begin{array}{r}14 \\
2\end{array}$ & $\begin{array}{l}0.47 \\
0.03\end{array}$ & $\begin{array}{r}68 \\
6\end{array}$ \\
\hline FRS III B5 & $\begin{array}{l}18-22.5 \mathrm{~cm} \\
(\text { upwards) }\end{array}$ & I & $\begin{array}{r}57 \\
2\end{array}$ & $\begin{array}{l}1.03 \\
0.03\end{array}$ & $\begin{array}{l}1.03 \\
0.03\end{array}$ & in $f$. & $\begin{array}{l}0.49 \\
0.11\end{array}$ & $\begin{array}{r}74 \\
+26-21\end{array}$ \\
\hline FRS III B6 & $\begin{array}{l}22.5-27 \mathrm{~cm} \\
(\text { upwards) }\end{array}$ & I & $\begin{array}{r}45 \\
2\end{array}$ & $\begin{array}{l}0.99 \\
0.05\end{array}$ & $\begin{array}{l}0.99 \\
0.05\end{array}$ & in $f$. & $\begin{array}{l}0.62 \\
0.04\end{array}$ & $\begin{array}{r}104 \\
+13-11\end{array}$ \\
\hline FRS III B7 & $\begin{array}{l}27-31.5 \mathrm{~cm} \\
(\text { upwards) }\end{array}$ & I & $\begin{array}{r}43 \\
1\end{array}$ & $\begin{array}{l}1.04 \\
0.06\end{array}$ & $\begin{array}{l}1.05 \\
0.06\end{array}$ & $\begin{array}{l}99 \\
26\end{array}$ & $\begin{array}{l}0.56 \\
0.03\end{array}$ & $\begin{array}{r}88 \\
8\end{array}$ \\
\hline FRS III B8 & $\begin{array}{l}31.5-36 \mathrm{~cm} \\
\text { (upwards) }\end{array}$ & I & $\begin{array}{r}34 \\
2\end{array}$ & $\begin{array}{l}1.12 \\
0.07\end{array}$ & $\begin{array}{l}1.18 \\
0.07\end{array}$ & $\begin{array}{l}65 \\
20\end{array}$ & $\begin{array}{l}0.70 \\
0.05\end{array}$ & $\begin{array}{r}132 \\
+18-16\end{array}$ \\
\hline FRS III B9 & $36-40.5 \mathrm{~cm}$ & G & $\begin{array}{r}41 \\
2\end{array}$ & $\begin{array}{l}1.03 \\
0.05\end{array}$ & $\begin{array}{l}1.03 \\
0.05\end{array}$ & inf. & $\begin{array}{l}0.26 \\
0.02\end{array}$ & $\begin{array}{r}33 \\
3\end{array}$ \\
\hline FRS III B10 & $40.5-45 \mathrm{~cm}$ & G & $\begin{array}{r}72 \\
4\end{array}$ & $\begin{array}{l}1.01 \\
0.06\end{array}$ & $\begin{array}{l}1.01 \\
0.06\end{array}$ & inf. & $\begin{array}{l}0.40 \\
0.02\end{array}$ & $\begin{array}{r}55 \\
5\end{array}$ \\
\hline FRS III B11 & top & G & $\begin{array}{r}39 \\
3\end{array}$ & $\begin{array}{l}1.04 \\
0.09\end{array}$ & $\begin{array}{l}1.04 \\
0.09\end{array}$ & inf. & $\begin{array}{l}0.13 \\
0.03\end{array}$ & $\begin{array}{r}15 \\
+4-3\end{array}$ \\
\hline FRS III C1 & $\begin{array}{l}75-85 \mathrm{~cm} \\
(\text { inwards })\end{array}$ & G & $\begin{array}{r}45 \\
2\end{array}$ & $\begin{array}{l}1.02 \\
0.05\end{array}$ & $\begin{array}{l}1.02 \\
0.05\end{array}$ & $\begin{array}{r}15 \\
2\end{array}$ & $\begin{array}{l}0.09 \\
0.01\end{array}$ & $\begin{array}{r}10 \\
3\end{array}$ \\
\hline
\end{tabular}




\begin{tabular}{|c|c|c|c|c|c|c|c|}
\hline FRS III C2 & $\begin{array}{l}65-75 \mathrm{~cm} \\
\text { (inwards) }\end{array}$ & I & $\begin{array}{r}48 \\
1\end{array}$ & $\begin{array}{l}1.11 \\
0.02\end{array}$ & $\begin{array}{l}1.11 \\
0.02\end{array}$ & inf. & $\begin{array}{l}0.07 \\
0.01\end{array}$ \\
\hline FRS III C8 & $\begin{array}{l}0-10 \mathrm{~cm} \\
\text { (inwards) }\end{array}$ & 1 & $\begin{array}{r}46 \\
7\end{array}$ & $\begin{array}{l}1.05 \\
0.04\end{array}$ & $\begin{array}{l}1.05 \\
0.04\end{array}$ & inf. & $\begin{array}{l}0.02 \\
0.01\end{array}$ \\
\hline FRS III E1 & $\begin{array}{l}100-110 \mathrm{~cm} \\
\text { (inwards) }\end{array}$ & I & $\begin{array}{r}40 \\
5\end{array}$ & $\begin{array}{l}1.09 \\
0.07\end{array}$ & $\begin{array}{l}1.09 \\
0.07\end{array}$ & inf. & $\begin{array}{l}0.08 \\
0.01\end{array}$ \\
\hline FRS III E2 & $\begin{array}{l}90-100 \mathrm{~cm} \\
\text { (inwards) }\end{array}$ & I & $\begin{array}{r}54 \\
2\end{array}$ & $\begin{array}{l}1.10 \\
0.03\end{array}$ & $\begin{array}{l}1.10 \\
0.03\end{array}$ & inf. & $\begin{array}{l}0.06 \\
0.01\end{array}$ \\
\hline FRS III E1O & $\begin{array}{l}0-10 \mathrm{~cm} \\
\text { (inwards) }\end{array}$ & G & $\begin{array}{r}23 \\
1\end{array}$ & $\begin{array}{l}1.13 \\
0.07\end{array}$ & $\begin{array}{l}1.14 \\
0.07\end{array}$ & inf. & $\begin{array}{l}0.14 \\
0.04\end{array}$ \\
\hline FRS III F1 & $\begin{array}{l}75-85 \mathrm{~cm} \\
\text { (inwards) }\end{array}$ & G & $\begin{array}{r}88 \\
1\end{array}$ & $\begin{array}{l}0.96 \\
0.04\end{array}$ & $\begin{array}{l}0.95 \\
0.04\end{array}$ & inf. & $\begin{array}{l}0.51 \\
0.03\end{array}$ \\
\hline FRS III G1 & $\begin{array}{l}100-110 \mathrm{~cm} \\
\text { (inwards) }\end{array}$ & I & $\begin{array}{r}59 \\
3\end{array}$ & $\begin{array}{l}0.93 \\
0.04\end{array}$ & $\begin{array}{l}0.81 \\
0.04\end{array}$ & inf. & $\begin{array}{l}0.55 \\
0.05\end{array}$ \\
\hline FSR III H1 & $\begin{array}{l}100-110 \mathrm{~cm} \\
\text { (inwards) }\end{array}$ & I & $\begin{array}{c}76 \\
3\end{array}$ & $\begin{array}{l}1.19 \\
0.04\end{array}$ & $\begin{array}{l}1.20 \\
0.04\end{array}$ & inf. & $\begin{array}{l}0.08 \\
0.01\end{array}$ \\
\hline FRS III H2 & $\begin{array}{l}90-100 \mathrm{~cm} \\
\text { (inwards) }\end{array}$ & G & $\begin{array}{r}51 \\
3\end{array}$ & $\begin{array}{l}1.07 \\
0.03\end{array}$ & $\begin{array}{l}1.07 \\
0.03\end{array}$ & inf. & $\begin{array}{l}0.10 \\
0.02\end{array}$ \\
\hline FRS III H4 & $\begin{array}{l}73-85 \mathrm{~cm} \\
\text { (inwards) }\end{array}$ & I & $\begin{array}{r}74 \\
2\end{array}$ & $\begin{array}{l}1.18 \\
0.03\end{array}$ & $\begin{array}{l}1.18 \\
0.03\end{array}$ & inf. & $\begin{array}{l}0.07 \\
0.01\end{array}$ \\
\hline FRS III H5 & $\begin{array}{l}60-73 \mathrm{~cm} \\
\text { (inwards) }\end{array}$ & I & $\begin{array}{r}65 \\
2\end{array}$ & $\begin{array}{l}1.21 \\
0.03\end{array}$ & $\begin{array}{l}1.21 \\
0.03\end{array}$ & inf. & $\begin{array}{l}0.07 \\
0.01\end{array}$ \\
\hline FRS III H6 & $\begin{array}{l}47-60 \mathrm{~cm} \\
\text { (inwards) }\end{array}$ & G & $\begin{array}{r}75 \\
4\end{array}$ & $\begin{array}{l}1.27 \\
0.06\end{array}$ & $\begin{array}{l}1.29 \\
0.06\end{array}$ & $\begin{array}{r}11 \\
2\end{array}$ & $\begin{array}{l}0.19 \\
0.01\end{array}$ \\
\hline FRS III H7 & $\begin{array}{l}35-47 \mathrm{~cm} \\
\text { (inwards) }\end{array}$ & I & $\begin{array}{r}54 \\
2\end{array}$ & $\begin{array}{l}1.22 \\
0.05\end{array}$ & $\begin{array}{l}1.22 \\
0.05\end{array}$ & inf. & $\begin{array}{l}0.08 \\
0.01\end{array}$ \\
\hline FRS III H8 & $\begin{array}{l}23-35 \mathrm{~cm} \\
\text { (inwards) }\end{array}$ & I & $\begin{array}{r}51 \\
2\end{array}$ & $\begin{array}{l}1.13 \\
0.05\end{array}$ & $\begin{array}{l}1.13 \\
0.05\end{array}$ & inf. & $\begin{array}{l}0.05 \\
0.01\end{array}$ \\
\hline FRS III H9 & $\begin{array}{l}10-23 \mathrm{~cm} \\
\text { (inwards) }\end{array}$ & I & $\begin{array}{r}57 \\
2\end{array}$ & $\begin{array}{l}1.24 \\
0.05\end{array}$ & $\begin{array}{l}1.24 \\
0.05\end{array}$ & inf. & $\begin{array}{l}0.05 \\
0.01\end{array}$ \\
\hline FRS III H1O & $\begin{array}{c}0-10 \mathrm{~cm} \\
\text { (inwards) }\end{array}$ & I & $\begin{array}{r}26 \\
2\end{array}$ & $\begin{array}{l}0.83 \\
0.09\end{array}$ & $\begin{array}{l}0.83 \\
0.09\end{array}$ & inf. & $\begin{array}{l}0.07 \\
0.01\end{array}$ \\
\hline FRS III LI & $\begin{array}{l}100-110 \mathrm{~cm} \\
\text { (inwards) }\end{array}$ & I & $\begin{array}{r}74 \\
4\end{array}$ & $\begin{array}{l}1.02 \\
0.05\end{array}$ & $\begin{array}{l}1.02 \\
0.07\end{array}$ & inf. & $\begin{array}{l}0.49 \\
0.04\end{array}$ \\
\hline FRS III L5 & $\begin{array}{l}55-65 \mathrm{~cm} \\
\text { (inwards) }\end{array}$ & G & $\begin{array}{r}52 \\
2\end{array}$ & $\begin{array}{l}1.05 \\
0.03\end{array}$ & $\begin{array}{l}1.05 \\
0.03\end{array}$ & inf. & $\begin{array}{l}0.38 \\
0.02\end{array}$ \\
\hline FRS III L10 & $\begin{array}{l}0-10 \mathrm{~cm} \\
\text { (inwards) }\end{array}$ & I & $\begin{array}{r}37 \\
1\end{array}$ & $\begin{array}{l}1.01 \\
0.04\end{array}$ & $\begin{array}{l}1.01 \\
0.04\end{array}$ & inf. & $\begin{array}{l}0.08 \\
0.01\end{array}$ \\
\hline FRS III MI 2 & $\begin{array}{l}20-30 \mathrm{~cm} \\
\text { (inwards) }\end{array}$ & I & $\begin{array}{r}39 \\
2\end{array}$ & $\begin{array}{l}1.10 \\
0.05\end{array}$ & $\begin{array}{l}1.10 \\
0.05\end{array}$ & inf. & $\begin{array}{l}0.01 \\
0.01\end{array}$ \\
\hline
\end{tabular}




\begin{tabular}{|c|c|c|c|c|c|c|c|c|}
\hline FRS 2 (III) & nucleus & $\mathbf{G}$ & $\begin{array}{r}53 \\
2\end{array}$ & $\begin{array}{l}0.92 \\
0.05\end{array}$ & $\begin{array}{l}0.92 \\
0.05\end{array}$ & inf. & $\begin{array}{l}0.10 \\
0.01\end{array}$ & $\begin{array}{r}12 \\
1\end{array}$ \\
\hline FRS 4 (III) & flowstone & I & $\begin{array}{r}91 \\
5\end{array}$ & $\begin{array}{l}0.99 \\
0.18\end{array}$ & $\begin{array}{l}0.99 \\
0.18\end{array}$ & $\begin{array}{r}1 \\
(*)\end{array}$ & $\begin{array}{l}0.02 \\
0.03\end{array}$ & $\begin{array}{l}4 \\
2\end{array}$ \\
\hline FRS IV A2 & top & $\mathbf{G}$ & $\begin{array}{r}67 \\
2\end{array}$ & $\begin{array}{l}1.02 \\
0.03\end{array}$ & $\begin{array}{l}1.03 \\
0.03\end{array}$ & $\begin{array}{r}12 \\
3\end{array}$ & $\begin{array}{l}0.10 \\
0.01\end{array}$ & $\begin{array}{r}11 \\
1\end{array}$ \\
\hline FRS IV B1 & base & $\mathbf{G}$ & $\begin{array}{r}71 \\
3\end{array}$ & $\begin{array}{l}0.91 \\
0.04\end{array}$ & $\begin{array}{l}0.91 \\
0.04\end{array}$ & $\begin{array}{r}1 \\
0.1\end{array}$ & $\begin{array}{l}0.11 \\
0.01\end{array}$ & 13 \\
\hline FRS IV B2 & top & G & $\begin{array}{r}29 \\
1\end{array}$ & $\begin{array}{l}1.07 \\
0.06\end{array}$ & $\begin{array}{l}1.08 \\
0.06\end{array}$ & $\begin{array}{r}1 \\
0.1\end{array}$ & $\begin{array}{l}0.11 \\
0.01\end{array}$ & 10 \\
\hline FRS V A1 & base & I & $\begin{array}{r}61 \\
3\end{array}$ & $\begin{array}{l}1.01 \\
0.04\end{array}$ & $\begin{array}{l}1.01 \\
0.04\end{array}$ & $\begin{array}{r}40 \\
9\end{array}$ & $\begin{array}{l}0.53 \\
0.03\end{array}$ & $\begin{array}{r}82 \\
8\end{array}$ \\
\hline FRS V A2 & top & $\mathbf{G}$ & $\begin{array}{r}54 \\
1\end{array}$ & $\begin{array}{l}1.06 \\
0.03\end{array}$ & $\begin{array}{l}1.06 \\
0.03\end{array}$ & $\begin{array}{r}10 \\
1\end{array}$ & $\begin{array}{l}0.30 \\
0.02\end{array}$ & $\begin{array}{r}39 \\
3\end{array}$ \\
\hline FRS V D1 & base & G & $\begin{array}{r}57 \\
3\end{array}$ & $\begin{array}{l}1.00 \\
0.04\end{array}$ & $\begin{array}{l}1.00 \\
0.04\end{array}$ & $\begin{array}{r}11 \\
1\end{array}$ & $\begin{array}{l}0.44 \\
0.03\end{array}$ & $\begin{array}{r}64 \\
+6-5\end{array}$ \\
\hline FRS V D2 & top & G & $\begin{array}{r}79 \\
3\end{array}$ & $\begin{array}{l}1.03 \\
0.03\end{array}$ & $\begin{array}{l}1.04 \\
0.03\end{array}$ & $\begin{array}{r}18 \\
7\end{array}$ & $\begin{array}{l}0.19 \\
0.26\end{array}$ & $\begin{array}{r}22 \\
+3-2\end{array}$ \\
\hline FRS V E1 & base & I & $\begin{array}{r}83 \\
5\end{array}$ & $\begin{array}{l}1.07 \\
0.07\end{array}$ & $\begin{array}{l}1.12 \\
0.07\end{array}$ & inf. & $\begin{array}{l}0.93 \\
0.06\end{array}$ & $\begin{array}{r}199 \\
+22-20\end{array}$ \\
\hline FRS V E2 & top & G & $\begin{array}{r}92 \\
4\end{array}$ & $\begin{array}{l}0.95 \\
0.03\end{array}$ & $\begin{array}{l}0.94 \\
0.03\end{array}$ & $\begin{array}{r}12 \\
2\end{array}$ & $\begin{array}{l}0.37 \\
0.02\end{array}$ & $\begin{array}{r}50 \\
4\end{array}$ \\
\hline FRS V F1 & $\begin{array}{l}\text { integrated } \\
\text { (see text) }\end{array}$ & I & $\begin{array}{r}35 \\
3\end{array}$ & $\begin{array}{l}1.51 \\
0.13\end{array}$ & $\begin{array}{l}1.51 \\
0.13\end{array}$ & inf. & $\begin{array}{l}0.01 \\
0.01\end{array}$ & $\begin{array}{l}2 \\
1\end{array}$ \\
\hline FRS 3a (V) & nucleus & I & $\begin{array}{r}78 \\
5\end{array}$ & $\begin{array}{l}1.02 \\
0.02\end{array}$ & $\begin{array}{l}1.02 \\
0.02\end{array}$ & $\begin{array}{r}12 \\
2\end{array}$ & $\begin{array}{l}0.48 \\
0.04\end{array}$ & $\begin{array}{r}71 \\
+8-7\end{array}$ \\
\hline FRS $3 b(V)$ & external & I & 46 & 1.10 & 1.10 & 23 & 0.05 & \\
\hline $\begin{array}{l}\text { FRS IIID1 } \\
\text { (VII) }\end{array}$ & $\begin{array}{l}100-110 \mathrm{~cm} \\
\text { (inwards) }\end{array}$ & G & $\begin{array}{r}41 \\
1\end{array}$ & $\begin{array}{l}1.00 \\
0.04\end{array}$ & $\begin{array}{l}1.00 \\
0.04\end{array}$ & inf. & $\begin{array}{l}0.76 \\
0.04\end{array}$ & $\begin{array}{r}157 \\
+21-18\end{array}$ \\
\hline FRS 1 (VII) & $\begin{array}{l}\text { external } \\
\text { layer of III D1 }\end{array}$ & I & $\begin{array}{r}69 \\
2\end{array}$ & $\begin{array}{l}1.02 \\
0.03\end{array}$ & $\begin{array}{l}1.03 \\
0.03\end{array}$ & inf. & $\begin{array}{l}0.69 \\
0.03\end{array}$ & $\begin{array}{r}124 \\
+12-11\end{array}$ \\
\hline
\end{tabular}

\# Age corrected for detrital thorium. 
Tab. 2 - Ages of the speleothems in relation to the evolution of the karst process.

\begin{tabular}{rccccc}
\hline $\begin{array}{l}\text { Karst } \\
\text { evel }\end{array}$ & $\begin{array}{c}\text { Height above } \\
\text { water table } \\
(\mathrm{m})\end{array}$ & $\begin{array}{c}\mathrm{N}^{\circ} \text { of } \\
\text { sampled } \\
\text { speleothems }\end{array}$ & $\begin{array}{c}\mathrm{N}^{\circ} \text { of } \\
\text { measured } \\
\text { samples }\end{array}$ & $\begin{array}{c}\text { Karst level } \\
\text { minimum } \\
\text { age (k•years) }\end{array}$ & $\begin{array}{c}\text { Related } \\
\text { climatic } \\
\text { event }\end{array}$ \\
\hline VII & +210 & 4 & 5 & $>200$ & $>$ Mindel-Riss \\
VI & +65 & - & - & $>200$ & $>$ Mindel-Riss \\
V & +52 & 16 & 21 & 200 & Mindel-Riss \\
IV & +35 & 2 & 3 & $200-130$ & Riss \\
III & +25 & 12 & 34 & 130 & Riss-Würm \\
II & +12 & 2 & 2 & 10 & Post-Würm \\
I & +2 & 2 & 1 & 10 & Post-Würm \\
\hline
\end{tabular}

